ARTIGOS / ARTICLES

\title{
Genetic Divergence Among and Within Colletotrichum lindemuthianum Races Assessed by RAPD
}

\author{
Viviane Talamini ${ }^{1}$, Elaine A. Souza ${ }^{2}$, Edson A. Pozza ${ }^{1}$, Gilvan F. Silva ${ }^{2}$, \\ Francine H. Ishikawa ${ }^{2} \&$ Osnil A. Camargo Júnior ${ }^{2}$
}

${ }^{1}$ Departamento de Fitopatologia, ${ }^{2}$ Departamento de Biologia, Universidade Federal de Lavras, Caixa Postal 3037, CEP 37200-000, Lavras, MG, E-mail: vivianetalamini@yahoo.com.br

(Accepted for publication 01/12/2006)

Author for correspondence: Viviane Talamini

TALAMINI, V., SOUZA, E.A., POZZA, E.A., SILVA, G.F., ISHIKAWA, F.H. \& CAMARGO JÚNIOR, O.A. Genetic Divergence Among and Within Colletotrichum lindemuthianum Races assessed by RAPD. Fitopatologia Brasileira 31:545550. 2006.

\begin{abstract}
Genetic divergence within and among races of Colletotrichum lindemuthianum was determined using RAPD markers. In addition to the different races of the fungus three isolates of the sexual stage of Colletotrichum lindemuthianum (Glomerella cingulata f.sp. phaseoli) were included in this study. The band patterns generated using 11 primers produced 133 polymorphic bands. The polymorphic bands were used to determine genetic divergence among and within the pathogen races. The isolates analyzed were divided into six groups with 0.75 relative similarity. Group VI, formed by three isolates of the sexual phase of Colletotrichum lindemuthianum, was the most divergent. Races previously determined using differential cultivars did not correlate with the results obtained using RAPD markers.
\end{abstract}

Additional Keywords: Phaseolus vulgaris, common bean, DNA, molecular characterization, variability.

\section{RESUMO \\ Divergência genética entre e dentro de raças de Colletotrichum lindemuthianum utilizando RAPD.}

A divergência genética entre raças de Colletotrichum lindemuthianum foi obtida utilizando marcadores RAPD. Além das diferentes raças deste fungo, foram incluídos neste estudo três isolados da fase sexuada de Colletotrichum lindemuthianum (Glomerella cingulata f.sp. phaseoli). A informação do padrão de bandas geradas utilizando 11 primers, permitiu a identificação de 133 bandas polimórficas. As bandas polimórficas foram utilizadas para determinar a divergência genética entre e dentro de raças do patógeno. Os isolados analisados foram distribuídos em seis grupos com similaridade relativa de 0,75. O grupo VI, formado pelos três isolados da fase sexual do Colletotrichum lindemuthianum, foi o mais divergente. As raças agrupadas previamente pelo uso de cultivares diferenciadoras não apresentou qualquer relação com a classificação obtida pelos marcadores RAPD.

Palavras-chave adicionais: Phaseolus vulgaris, feijão comum, DNA, caracterização molecular, variabilidade.

\section{INTRODUCTION}

Colletotrichum lindemuthianum (Sacc. \& Magnus) Scribn., causal agent of anthracnose in common bean (Phaseolus vulgaris L.), is widely distributed in bean-producing regions of Minas Gerais State and in other locations in Brazil. Association of the pathogen with various crops and the different environmental conditions found from region to region may lead to the high pathogenic variability which has been observed in this fungus. This diversity may be mostly the result of the pathogenhost co-evolution (Alzate-Marin et al., 1999). A number of races may be found in each producing region, which may hinder the development of cultivar resistance to C. lindemuthianum (Rava et al., 1994).

Genetic and biochemical markers can provide new means to study genetic variability in phytopathogenic fungi (Maclean et al., 1993). RAPD markers permit the direct analysis of genome variations without environmental influence. Thus the polymorphisms found among $C$. lindemuthianum isolates detected by RAPD can facilitate studies on genetic diversity within and among races determined by a differential cultivar system (AlzateMarin et al., 1999). In previous studies using RAPD markers, band patterns generated by 44 primers enabled the determination of the genetic distance between isolates of races 64, 65, and 73. These data grouped these isolates in three groups which were coincident with the results obtained by inoculating the differential cultivars (Mesquita et al., 1998). Other RAPD studies have confirmed the high variability of $C$. lindemuthianum but these data did not correlate with those obtained by inoculation of differential cultivars (Vilarinhos et al., 1995; Alzate Marin et al., 1997; 2001; Thomazella et al., 2002).

Gonzalez et al. (1998) used the RAPD technique and detected a slight tendency to group isolates in relation to the geographic origin and did not observe direct correlation between 
genotype and races identified by inoculation in the differential cultivars. Similar results were obtained by Sicard et al. (1997). However, in another study, the relationship between geographic origin and clustering by this technique was not observed (Fabre et al., 1995). Thus, the present study was carried out to determine if genetic variation found in C. lindemuthianum, including isolates of the sexual stage of the pathogen, Glomerella cingulata f.sp.phaseoli Kimati, can be correlated with race using RAPD markers.

\section{MATERIALS AND METHODS}

The study was carried out in the Laboratory of Plant Disease Resistance, in a greenhouse, and in the Molecular Genetics laboratory located in the experimental area of the Department of Biology and the Epidemiology and Management Laboratory of the Plant Pathology Department, both at the Federal University of Lavras (UFLA).

\section{Colletotrichum lindemuthianum race isolates}

Isolates of $C$. lindemuthianum obtained from naturally infected common bean cultivars were used in this study. Small pieces of infected plant tissue were surface-sterilized and placed on Petri dishes containing M3 culture medium, and each isolate was purified by single spore isolation technique.

Thirty-one isolates were collected from three regions from Minas Gerais State, Brazil: Coromandel and Patos de Minas (Alto
Paranaíba Region); Lavras, Luminárias and Lambari(Sul de Minas Region); and Viçosa (Zona da Mata Region). Four were collected from other States of Brazil: one from Cristalina, Goiás State; one from Pindamonhangaba, São Paulo State; and two from Lapa, Paraná State. Three isolates previously identified and stored in the laboratory were also used, one of race 55 from Embrapa CNPAF (Santo Antonio de Goiás-GO) and two belonging to races 89 and 2047 from the Resistance Laboratory of the Department of Biology at UFLA. Three isolates of the sexual stage of $C$. lindemuthianum (Glomerella cingulata f.sp. phaseoli) obtained from a single ascospore in plates with colonies of the $C$. lindemuthianum race 73 were also included in this experiment. Therefore, 41 isolates were used in this study (Table 1).

The isolates were races determined by inoculation in the set of 12 differential cultivars proposed by the Latin American Meeting for Anthracnose in the common bean plant, held at the International Center for Tropical Agriculture (Cali, Colombia) (Ciat, 1990). The identified races were assigned a value based on the binary nomenclature system (Habgood, 1970).

\section{DNA extraction and RAPD marker generation}

Mycelia for DNA extraction were obtained by inoculating liquid M3 culture medium (Junqueira et al., 1984) and incubating at $20^{\circ} \mathrm{C}$ with agitation at 110 RPM rotation until abundant, pale-colored mycelia were obtained (between 5 to 7 days). The mycelia were freeze-dried for 24 hours and stored in a cool, dry

TABLE 1 - Geographic origin and races of isolates of Colletotrichum lindemuthianum used in the RAPD

\begin{tabular}{|c|c|c|c|c|c|}
\hline Isolate & $\begin{array}{l}\text { Region of } \\
\text { the origin }\end{array}$ & $\mathbf{R A C E} / \mathbf{N}^{\circ}$ & Isolate & $\begin{array}{l}\text { Region of } \\
\text { the origin }\end{array}$ & $\mathbf{R A C E} / \mathbf{N}$ \\
\hline 1 & Sul de Minas & $8 * 1$ & 21 & Zona da Mata & $81 * 3$ \\
\hline 2 & EMBRAPA/CNPAF $^{1}$ & $55 * 1$ & 22 & Zona da Mata & $81 * 4$ \\
\hline 3 & Lapa/PR & $64 * 1$ & 23 & Alto Paranaíba & $81 * 5$ \\
\hline 4 & Sul de Minas & $64 * 2$ & 24 & Sul de Minas & $81 * 6$ \\
\hline 5 & Zona da Mata & $65 * 1$ & 25 & Sul de Minas & $81 * 7$ \\
\hline 6 & Zona da Mata & $65 * 2$ & 26 & Zona da Mata & $83 * 1$ \\
\hline 7 & Zona da Mata & $65 * 3$ & 27 & Zona da Mata & $87 * 1$ \\
\hline 8 & Zona da Mata & $65 * 4$ & 28 & Zona da Mata & $87 * 2$ \\
\hline 9 & Sul de Minas & $65 * 5$ & 29 & Alto Paranaíba & $87 * 3$ \\
\hline 10 & Sul de Minas & $65 * 6$ & 30 & Sul de Minas & $89 * 1$ \\
\hline 11 & Sul de Minas & $65 * 7$ & 31 & DBI/UFLA & $89 * 2$ \\
\hline 12 & Alto Paranaíba & $65 * 8$ & 32 & Zona da Mata & $337 * 1$ \\
\hline 13 & Zona da Mata & $65 * 9$ & 33 & Zona da Mata & $337 * 2$ \\
\hline 14 & Sul de Minas & $65 * 10$ & 34 & Zona da Mata & $337 * 3$ \\
\hline 15 & Sul de Minas & $65 * 11$ & 35 & Zona da Mata & $337 * 4$ \\
\hline 16 & Pindamonhangaba/SP & $73 * 1$ & 36 & Cristalina/GO & $593 * 1$ \\
\hline 17 & Sul de Minas & $73 * 2$ & 37 & DBI/UFLA ${ }^{2}$ & $2047 * 1$ \\
\hline 18 & Sul de Minas & $73 * 3$ & 38 & Lavras $^{3}$ & $73 * 1$ \\
\hline 19 & Alto Paranaíba & $81 * 1$ & 39 & Lavras $^{3}$ & $73 * 2$ \\
\hline \multirow[t]{2}{*}{20} & Sul de Minas & $81 * 2$ & 40 & Lavras $^{3}$ & $73 * 3$ \\
\hline & & & 41 & Lapa/PR & $0 * 1$ \\
\hline
\end{tabular}

${ }^{1}$ Embrapa, Centro Nacional de Pesquisas de Arroz e Feijão - CNPAF.

${ }^{2}$ Laboratory of Plant Disease Resistance of the Department of Biology at Federal University of Lavras, UFLA.

${ }^{3}$ Glomerella cingulata f.sp. phaseoli. 
environment for later DNA extraction. DNA was extracted according to methodology by Roaeder and Broda (1987) with modifications.

Twenty-one primers from Operon Technologies were used to analyze the genetic variability of the $C$. lindemuthianum isolates. Some primers were designated at random and others were based on related articles, for example: OPAT09 and OPAT18 primers were used by Mesquita et al. (1998), and Alzate-Marin et al., (2001) (Table 2).

Each RAPD reaction contained 30ng of DNA, $100 \mu \mathrm{M}$ of each dNTP; $04 \mu \mathrm{M}$ primer; 0.6U Taq DNA polymerase; $2.5 \mathrm{mM} \mathrm{MgCl}_{2} ; 20 \mathrm{mM} \mathrm{KCl} ; 50 \mathrm{mM}$ Tris $\mathrm{pH} 8.3 ; 250 \mu \mathrm{g}$ bovine serum albumin $/ \mathrm{mL} ; 1 \%$ de ficoll $400 ; 1 \mathrm{mM}$ tartrazine and water up to final volume of $16 \mu \mathrm{L}$ (Hagiwara et al., 2001). Amplification reaction was conducted in a Gradient 5331 Eppendorf Master Cycler thermocycler, programmed for 39 cycles. In the first two cycles, the denaturation was conducted at $94{ }^{\circ} \mathrm{C}$ for 2 minutes, annealing at $37^{\circ}$ for 15 seconds, and elongation at $72{ }^{\circ} \mathrm{C}$ for 60 seconds followed by an additional 37 cycles, which differed for denaturation by 15 seconds. A final extension was done for 2 minutes at $72^{\circ} \mathrm{C}$. The RAPD fragments were analyzed by agarose gel electrophoresis at a concentration of $1 \%$ agarose in $1 \mathrm{X}$ TBE buffer. The bands were visualized under ultra-violet light and photographed with Polaroid 667 film.

\section{Analysis of RAPD markers}

Polymorphic bandswere confirmedintworeplications. They were scored for each individual based on presence or absence. The genetic similarity was estimated by the Nei and Li procedure by the expression $\mathrm{sg}_{\mathrm{ij}}=2 \mathrm{a} /(2 \mathrm{a}+\mathrm{b}+\mathrm{c})$, where $\mathrm{a}=$ presence of a determined band in the individuals $i$ and $j ; b=$ presence of the band in $\mathrm{i}$ and absence in $\mathrm{j} ; \mathrm{c}=$ absence of the band in $\mathrm{i}$ and presence in $\mathrm{j}$. Cluster analysis was performed using the mean of similarities method (UPGMA) using the NTSYS-PC 2.0 program (Rohlf, 1992).

\section{RESULTS AND DISCUSSION}

Eleven of the twenty-one primers used produced band patterns in each of the two replicate reactions (Table 2) and were used to analyze the $41 C$. lindemuthianum isolates. One hundred and thirty-three polymorphic bands could be identified across all isolates and these were analyzed to determine genetic similarity among isolates and construct the dendogram (Figure 1). The isolates analyzed in this study were divided into six groups with 0.75 relative similarity. Group I was formed by an isolate of the races 8, 64, 83, 593, 55,0 , two isolates from races 73 and 89 , three isolates from races 87 and 337, seven isolates from race 81 and seven isolates of race 65 . Group II was formed by one isolate of race 2047, group III was formed by one isolate of race 65 , group IV by one isolate of races 64,73 and 337 and two isolates from race 65 . Group $\mathrm{V}$ was formed by one isolate from race 65 and group VI was formed by three isolates of the sexual stage G. cingulata f.sp. phaseoli (Figure 1).
The greatest similarity was correlated with the region of origin, regardless of the isolate race. With 0.98 similarity, races $83 * 1$ and $87 * 1$ and races $337 * 2$ and $337 * 3$ were from the Zona da Mata Region. Races $65 * 4$ and $337 * 4$ (0.97 similarity) are also from the Zona da Mata, as were races $81 * 1$ and $81 * 5$ (0.97 similarity) from Alto Paranaíba. Races $81 * 1$ and $81 * 5$ (0.97 similarity) were from the Alto Paranaíba Region, and races $81 * 6$ and $81 * 7$ (0.96 similarity) and $73 * 2$ and $89 * 1$ (0.94 similarity) were from the Sul de Minas region. Group VI was the least similar of all of the other groups ( 0.28 similarity). The isolates in this group were each isolated from a single ascospore of Glomerella cingulata f. sp. phaseoli, the sexual stage of Colletotrichum lindemuthianum. The lack of similarity of these isolates to others in this study may be due to recombination events during sexual reproduction.

In this study the effect of region of origin seemed to increase as the similarity among the isolates decreased. The interchange of seeds infected with $C$. lindemuthianum among regions may contribute to isolates from different regions grouping together in several specific examples. For example, among races $65 * 3,81 * 3,83 * 1$ and $87 * 1(0.94$ similarity) three isolates are from the Zona da Mata and one from the Sul de Minas $(81 * 3)$, which may indicate the transport of isolates from more distant regions to the Sul de Minas. Other isolates also presented less similarity even when from the same region and race $(65 * 9$ and $65 * 2$ with 0.30 similarity).

The lack of correlation between the $C$. lindemuthianum isolate origin and the cluster was observed in the study by Fabre et al. (1995) with isolates from Latin America present in all groups. In the pathosystem wheat $\mathrm{x}$ Drechslera triticirepentis the RAPD analysis of 12 isolates of this pathogen, from three different regions of Rio Grande do Sul State, also showed the lack of relationship among the genotypes and the region of origin (Santos et al., 2001). Lack of relationship among the groups formed by RAPD and the geographic origin of those isolates may be attributed to the breeding methods, which are based on the introduction and assessment of many lines of different origins. This may

TABLE 2 - Relation of primers used which presented polymorphic and similar band patterns in each of the two replicate reactions

\begin{tabular}{lcc}
\hline \hline Primers & Polymorphics Bands & Sequences 5'-3' \\
\hline OPAA01 & 10 & AGACGGCTCC \\
OPAA16 & 11 & GGAACCCACA \\
OPBB12 & 7 & TTCGGCCGAC \\
OPAT 09 & 10 & CCGTTAGCGT \\
OPAT18 & 10 & CCAGCT GTGA \\
OPAT19 & 14 & ACCAAGGCAC \\
OPZ03 & 12 & CAGCACCGCA \\
OPZ06 & 11 & GTGCCGTTCA \\
OPZ07 & 16 & CCAGGAGGAC \\
OPZ10 & 13 & CCGACAAACC \\
OPZ19 & 19 & GTGCGAGCAA \\
\hline
\end{tabular}




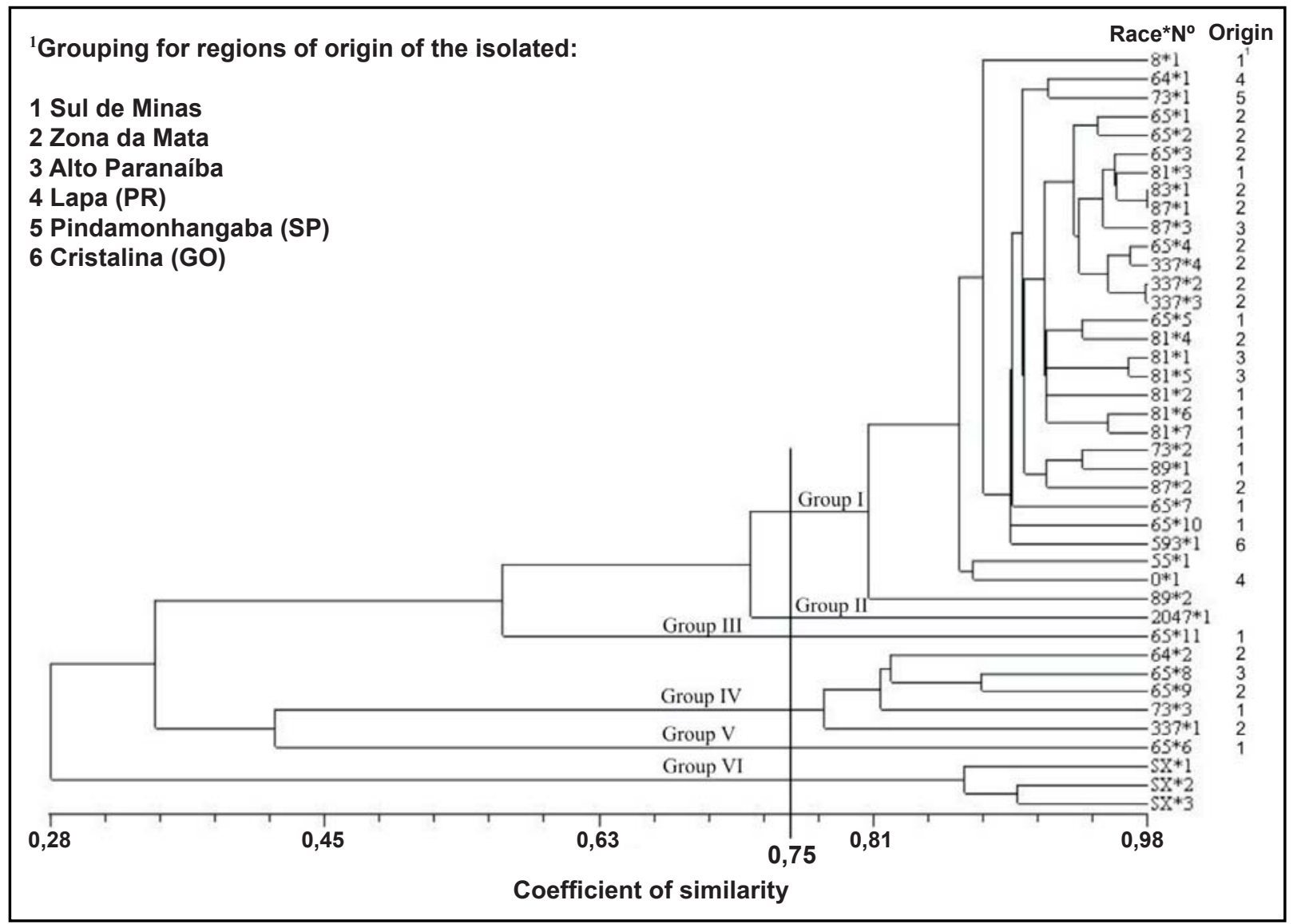

FIG. 1 - Genetic similarity between races of Colletotrichum lindemuthianum. SX: Glomerella cingulata f.sp. phaseoli.

result in the high variability of the pathogen (Alzate-Marin et al., 1997; González et al., 1998).

González et al. (1998) suggested a certain tendency to group isolates by geographic origin using RAPD data, but these authors obtained better performance with AFLP data, which showed a clear association between the region of origin and genetic distance. According to the same authors AFLP data did not correlate with race. Both RAPD and AFLP data randomly sample the entire genome and may not sample regions associated with pathogenicity.

Specific bands for single isolates of races 73 and 65 were observed in the study by Mesquita et al. (1998) using the OPAT09 and OPAT18 primers, respectively. In the present study, the OPAT09 and OPAT18 primers were tested and specific bands for races 73 and 65 were not observed. Alzate-Marin et al. (2001) tested these primers to verify the presence or absence of the specific bands reported and did not find the existence of specific bands either. According to Alzate-Marin et al. (2001), the lack of repeatability in the results among the studies may be explained by greater sampling of isolates within the same race when compared to the study by Mesquita et al. (1998) that used only a single isolate from each race. Thus sampling within races and geographic locations, as well as the number of races sampled, are critical to the interpretation of results. Completely different results may be obtained when only a few isolates belonging to few races are compared with analyses of larger number of isolates per race. Relationships between a large number of isolates belonging to the same race may also not be comparable to analyses of races represented by a single individual (Alzate-Marin et al., 2001).

Another important finding was the lack of relationship between RAPD clusters and the races identified in the differential cultivars system, corroborating the results obtained by Vilarinhos et al. (1995), Thomazella et al. (2002), Balardin, (1997) and Alzate-Marin et al. (1997, 2001). In these studies, using the same RAPD technique, these authors placed the races in groups different from those defined by the differential cultivars. The amplified portions of the pathogen genome may not have correlated with the avirulence alleles because the primers searched random regions in the genome (Alzate-Marin et al., 1997; Maclean et al., 1993). This fact alone may justify the lack of close relationship between the grouping by RAPD markers and their race based on differential cultivars.

Many factors may be responsible for this finding. $G$. cingulata f.sp phaseoli have been observed a few times after attempted crosses in laboratories, but it is difficult for this to occur in nature (Bryson et al., 1992); nevertheless, high variation is observed at their asexual stage. There are reports 
of variation occurring in C. lindemuthianum monosporic isolates when kept and cultivated in the laboratory (Rocca, 2004). Mutation is a basic source of genetic variation for asexually reproducing fungi (Hastie, 1981). However, observations of nuclear migration between two or more conidia connected by anastomosis may explain some of the variability detected in $C$. lindemuthianum. In this event, many data can be obtained or lost during the asexual cycle by recombination (Roca, 2004). Other factors may be linked to the genetic variability in any given study, such as the number of isolates selected for analysis, the type of organism studied, the selection pressure and migration (Santos et al., 2002). Phytopathogenic organisms are constantly subject to extinction and re-colonization and are rarely found in equilibrium (Peever \& Milgroom, 1994). The process of co-evolution resulting from selection pressure exerted by the plant and the pathogen is considered to be a potential mechanism acting on virulence diversity.

The high variability of the $C$. lindemuthianum makes it difficult to breed for anthracnose resistance. The use of genetic resistance as a method to control the disease economically is of great interest. Therefore, information about the variability of the fungus in each region is the basis for resistance breeding programs (Balardin, 1997). The use of pathogenicity and molecular analysis together will lead to a better understanding of the variability present in $C$. lindemuthianum. This information is critical for anthracnose management strategies, selection of resistance genes and development of resistant commercial bean cultivars (Mahuku \& Riascos, 2004).

This study permitted the authors to verify that the use of differential cultivars is still of the most importance for checking the variability of the pathogen and classifying its isolates in races within the regions. The pathogenicity and RAPD markers corroborated the broad genetic diversity of $C$. lindemuthianum and can be used as tools to improve the investigation into the fungus variability and, thus, help breeding programs in choice the source of resistance for each region.

\section{ACKNOWLEDGEMENTS}

We thank Dr. João Bosco dos Santos for facilitating access to the Molecular Biology Laboratory, UFLA, and to CAPES and FAPEMIG for financial support.

\section{REFERENCES}

ALZATE-MARIN, A.L., BARROS, E.G. \& MOREIRA, M.A. Co-evolution model of Colletotrichum lindemuthianum (Melanconiaceae, Melanconiales) races that occur in some Brazilian regions. Genetics and Molecular Biology 22:115-118. 1999.

ALZATE-MARIN, A.L., MAÍA, G., FALEIRO, F.G., CARVALHO, G.A., PAULA, J.R. T.J., MOREIRA, M.A. \& BARROS, E.G.
Análise da diversidade genética de raças de Colletotrichum lindemuthianum que ocorrem em algumas regiões do Brasil por marcadores RAPD. Fitopatologia Brasileira 22:85-88. 1997.

ALZATE-MARIN, A.L., NIETSCHE S., COSTA M.R., SOUZA K.A., SARTORATO A., BARROS E.G. \& MOREIRA M.A. Análise do DNA de isolados de Colletotrichum lindemuthianum e Phaeoisariopsis griseola visando identificação de patótipos. Summa Phytopathologica 27:196-202. 2001.

BALARDIN, R.S. Identificação de raças fisiológicas de Colletotrichum lindemuthianum no Rio Grande do Sul - Brasil. Fitopatologia Brasileira 22:50-53. 1997.

BRYSON, R.J., CATEN, C.E., HOLLOMON, D.W., \& BAILEY, J.A. Sexuality and genetics of Colletotrichum. In: Bailey, J.A.; Jeger, M.J. (Eds.) Colletotrichum: biology, pathology and control. Wallingford. CAB International, 1992. pp. 27-47

CIAT. Centro Internacional de Agricultura Tropical. Informe anual, 1988. Programa in Frijol. Cali. CIAT. Working Document 72:128129. 1990.

FABRE, L.V., JULIEN, J., PARISOT, D. \& DRON, M. Analysis of diverse isolates of Colletotrichum lindemuthianum infecting common bean using molecular markers. Mycological Research 99:429-435. 1995.

GONZÁLEZ, M., RODRÍGUEZ, R., ZAVALA, M.E., JACOBO, J.L., HERNÁNDEZ, J.A., MARTINEZ, O. \& SIMPSON, J. Characterization of Mexican isolates of Colletotrichum lindemuthianum by using differential cultivars and molecular markers. Phytopathology 88:292-299. 1998.

HABGOOD, R.M. Designation of physiologic races of plant pathogens. Nature 227:1268-1269. 1970.

HAGIWARA, W.E., SANTOS, J.B. \& CARMO, S.L.M. Use of RAPD to aid selection in common bean backcross breeding programs. Crop Breeding and Applied Biotechnology 1: 355-362. 2001.

HASTIE, A.C. The genetics of conidial fungi. In: Cole, G.T. \& Kendrick, B. (eds). Biology of conidial fungi. New York. Academic Press. 1981. pp. 511-547.

JUNQUEIRA, N.T.V., CHAVES, G.M., ZAMBOLIM, L., ROMEIRO, R.S. \& GASPAROTTO, R. Isolamento, cultivo e esporulação de Microcyclus ulei, agente etiológico do mal-dasfolhas da seringueira. Revista Ceres 31:322-331. 1984.

MACLEAN, D.J., BRAITHWAITE, K.S., MANNERS, J.M. \& IRWIN, J.A.G. How do we identify and classify fungal plant pathogens in the era of DNA analysis? Advances in Plant Pathology 10:207-244. 1993.

MAHUKU, G.S. \& RIASCOS, J.J. Virulence and molecular diversity within Colletotrichum lindemuthianum isolates from Andean and Mesoamerican bean varieties and regions. European Journal of Plant Pathology 110:253-263. 2004.

MESQUITA, A.G.G., PAULA JUNIOR, T.J., MOREIRA, M.A. \& BARROS, E.G. Identification of races of Colletotrichum lindemuthianum with the aid of PCR-based molecular markers. Plant Disease 82:1084-1087. 1998.

PEEVER, T.L. \& MILGROOM, M.G. Genetic structure of Pyrenophora teres populations determined with random amplified polymorphic DNA markers. Canadian Journal of Botany 72:915923. 1994. 
RAVA, C.A., PURCHIO, A.F. \& SARTORATO, A. Caracterização de patótipos de Colletotricum lindemuthianum que ocorrem em algumas regiões produtoras de feijoeiro comum. Fitopatologia Brasileira 19:167-172. 1994.

RAEDER, V. \& BRODA, P. Rapid preparation of DNA from filamentous fungi. Letters in Applied Microbiology 1:17-20. 1987.

ROCA, M.G., DAVIDE, L.C., DAVIDE, L.M., MENDES-COSTA, M.C., SCHWAN, R. \& WHEALS A.E. Conidial anastomosis fusion between Colletotrichum spp. Mycological Research 108:13201326. 2004

ROHLF, F.J. Numerical taxonomy and multivariate analysis system. Version 1.70. Exeter Software. New York. State University of New York. 1992.

SANTOS, A.M.V., MATSUMURA, A.T.S. \& VAN DER SAND, S.T. Intraspecific genetic diversity of Drechslera tritici-repentis as detected by random amplified polymorphic DNA analysis. Genetics and Molecular Biology 25:243-250. 2002.
SARTORATO, A. Determinação da variabilidade patogênica do fungo Colletotrichum lindemuthianum (Sacc.) Scrib. Anais, VII Congresso Nacional de Pesquisa de Feijão, Universidade Federal de Viçosa, Viçosa, MG, 2000. pp. 114-116.

SICARD, D., MICHALAKIS, Y., DRON, M. \& NEEMA, C. Genetic diversity and pathogenic variation of Colletotrichum lindemuthianum in the three centers of diversity of its host, Phaseolus vulgaris. Phytopathology 87:807-813. 1997.

THOMAZELLA, C., GONÇALVES-VIDIGAL, M.C., VIDIGAL FILHO, P.S., BARELLI, M.A.A. \& SILVÉRIO, L. Divergência genética entre e dentro de raças de Colletotrichum lindemuthianum, determinada por marcadores RAPD. Anais, VII Congresso Nacional de Pesquisa de Feijão, Universidade Federal de Viçosa, Viçosa, MG. 2002. pp. 35-37.

VILARINHOS, A., PAULA JUNIOR, T.J., BARROS, E.G. \& MOREIRA, M.A. Characterization of races of Colletotrichum lindemuthianum by the random amplified polymorphic DNA technique. Fitopatologia Brasileira 20:194-198. 1995. 